\title{
Article \\ Neptunium and Uranium Interactions with Environmentally and Industrially Relevant Iron Minerals
}

\author{
Luke T. Townsend ${ }^{1,2}{ }^{\circledR}$, Kurt F. Smith ${ }^{1}$, Ellen H. Winstanley ${ }^{1}{ }^{\circledR}$, Katherine Morris ${ }^{1}$, Olwen Stagg ${ }^{1}{ }^{(0}$,

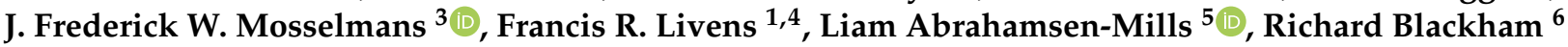 \\ and Samuel Shaw $1, * \mathbb{D}$
}

check for updates

Citation: Townsend, L.T.; Smith, K.F.; Winstanley, E.H.; Morris, K.; Stagg, O.; Mosselmans, J.F.W.; Livens, F.R.; Abrahamsen-Mills, L.; Blackham, R.; Shaw, S. Neptunium and Uranium Interactions with Environmentally and Industrially Relevant Iron Minerals. Minerals 2022, 12, 165. https://doi.org/10.3390/ $\min 12020165$

Academic Editor: Frank Heberling

Received: 14 January 2022

Accepted: 26 January 2022

Published: 28 January 2022

Publisher's Note: MDPI stays neutral with regard to jurisdictional claims in published maps and institutional affiliations.

Copyright: (c) 2022 by the authors. Licensee MDPI, Basel, Switzerland. This article is an open access article distributed under the terms and conditions of the Creative Commons Attribution (CC BY) license (https:// creativecommons.org/licenses/by/ $4.0 /)$.
1 Williamson Research Centre for Molecular Environmental Science and Research Centre for Radwaste Disposal, Department of Earth and Environmental Science, School of Natural Sciences, The University of Manchester, Oxford Road, Manchester M13 9PL, UK; l.townsend@sheffield.ac.uk (L.T.T.); kurt.francis.smith@gmail.com (K.F.S.); ellen.winstanley@nsgltd.com (E.H.W.); katherine.morris@manchester.ac.uk (K.M.); olwen.stagg@manchester.ac.uk (O.S.); francis.livens@manchester.ac.uk (F.R.L.)

2 Immobilisation Science Laboratory, Department of Materials Science and Engineering, University of Sheffield, Sheffield S1 3JD, UK

3 Diamond Light Source Ltd., Diamond House, Harwell Science and Innovation Campus, Didcot, Oxfordshire OX11 0DE, UK; fred.mosselmans@diamond.ac.uk

4 Centre for Radiochemistry Research, Department of Chemistry, The University of Manchester, Manchester M13 9PL, UK

5 National Nuclear Laboratory, Chadwick House, Warrington WA3 6AE, UK; liam.abrahamsen-mills@uknnl.com

6 Sellafield Ltd., Seascale, Cumbria CA20 1PG, UK; richard.a.blackham@sellafieldsites.com

* Correspondence: sam.shaw@manchester.ac.uk

Abstract: Neptunium $\left({ }^{237} \mathrm{~Np}\right)$ is an important radionuclide in the nuclear fuel cycle in areas such as effluent treatment and the geodisposal of radioactive waste. Due to neptunium's redox sensitivity and its tendency to adsorb strongly to mineral phases, such as iron oxides/sulfides, the environmental mobility of $\mathrm{Np}$ can be altered significantly by a wide variety of chemical processes. Here, $\mathrm{Np}$ interactions with key iron minerals, ferrihydrite $\left(\mathrm{Fe}_{5} \mathrm{O}_{8} \mathrm{H} \cdot 4 \mathrm{H}_{2} \mathrm{O}\right)$, goethite $(\alpha-\mathrm{FeOOH})$, and mackinawite (FeS), are investigated using X-ray Absorption Spectroscopy (XAS) in order to explore the mobility of neptunyl $(\mathrm{V})\left(\mathrm{Np}(\mathrm{V}) \mathrm{O}_{2}{ }^{+}\right)$moiety in environmental (radioactive waste disposal) and industrial (effluent treatment plant) scenarios. Analysis of the $\mathrm{Np} \mathrm{L}_{\mathrm{III}}$-edge $\mathrm{X}$-ray Absorption Near-Edge Structure (XANES) and Extended X-ray Absorption Fine Structure (EXAFS) showed that upon exposure to goethite and ferrihydrite, $\mathrm{Np}(\mathrm{V})$ adsorbed to the surface, likely as an inner-sphere complex. Interestingly, analysis showed that only the first two shells $\left(\mathrm{O}_{\mathrm{ax}}\right.$ and $\left.\mathrm{O}_{\mathrm{eq}}\right)$ of the EXAFS could be modelled with a high degree of confidence, and there was no clear indication of Fe or carbonate in the fits. When $\mathrm{Np}(\mathrm{V}) \mathrm{O}_{2}{ }^{+}$was added to a mackinawite-containing system, $\mathrm{Np}(\mathrm{V})$ was reduced to $\mathrm{Np}(\mathrm{IV})$ and formed a nanocrystalline $\mathrm{Np}(\mathrm{IV}) \mathrm{O}_{2}$ solid. An analogous experiment was also performed with $\mathrm{U}(\mathrm{VI}) \mathrm{O}_{2}{ }^{2+}$, and a similar reduction was observed, with $\mathrm{U}(\mathrm{VI})$ being reduced to nanocrystalline uraninite $\left(\mathrm{U}(\mathrm{IV}) \mathrm{O}_{2}\right)$. These results highlight that $\mathrm{Np}(\mathrm{V})$ may undergo a variety of speciation changes in environmental and engineered systems whilst also highlighting the need for multi-technique approaches to speciation determination for actinyl (for example, $\mathrm{Np}(\mathrm{V}) \mathrm{O}_{2}{ }^{+}$) species

Keywords: neptunium; uranium; iron (oxyhydr) oxide; iron sulfide; geological disposal of radioactive waste; contaminated land; EARP

\section{Introduction}

Neptunium $\left({ }^{237} \mathrm{~Np}\right)$ is a key radionuclide of interest in radioactive waste due to its long half-life $\left(t_{1 / 2}=2.14 \times 10^{6}\right.$ years) $[1,2]$. This transuranic element can be highly mobile in the natural environment [3-5] and exhibits significant radiotoxicity towards mammals [6]. 
${ }^{237} \mathrm{~Np}$ is produced from ${ }^{238} \mathrm{U}$ in nuclear reactors by neutron capture [7] and the $\alpha$-decay of ${ }^{241} \mathrm{Am}\left(\mathrm{t}_{1 / 2}=432.5\right.$ years) [1] in radioactive wastes, meaning the concentration of ${ }^{237} \mathrm{~Np}$ will increase in radioactive wastes over time. Additionally, ${ }^{237} \mathrm{~Np}$ is often considered a priority radionuclide for removal from radioactive effluents by treatment facilities, for example, the Enhanced Actinide Removal Plant (EARP, Sellafield, UK) [8-10], with research into its behaviour offering insight into $\mathrm{AnO}_{2}{ }^{+}$(e.g., $\mathrm{PuO}_{2}{ }^{+}$) behaviour more generally. Consequently, there is a need to obtain a mechanistic understanding of the solid-aqueous partitioning of $\mathrm{Np}$ in both natural and engineered environments.

$\mathrm{Np}$ exhibits variable environmental mobility in part due to its redox sensitivity, with the $+3,+4,+5$, and +6 oxidation states all available, each with differing levels of solubility in aqueous systems. However, under environmentally relevant conditions, $\mathrm{Np}(\mathrm{IV})$ and $\mathrm{Np}(\mathrm{V})$ tend to dominate [7]. Generally, oxidising conditions give rise to $\mathrm{Np}(\mathrm{V})$, typically present as the neptunyl $\left(\mathrm{NpO}_{2}{ }^{+}\right)$moiety, which is predicted to be highly mobile in the environment due to its high solubility. Under anaerobic conditions where $\mathrm{Np}(\mathrm{IV})$ dominates, solubility is controlled by the precipitation of poorly soluble $\mathrm{Np}(\mathrm{IV}) \mathrm{O}_{2}$ (s) [4]. Np mobility can be altered further through interactions with solid mineral phases, such as iron (oxyhydr)oxides and iron sulfides [11-21], which are naturally present and ubiquitous throughout subsurface environments relevant to geological disposal of radioactive wastes. Additionally, these mineral phases have potential for use in contaminated land remediation techniques targeting a multitude of metal contaminants, including Np [21,22]. Generally, Np may interact with the surface of Fe(III)-(oxyhydr)oxides (including ferrihydrite $\left(\mathrm{Fe}_{5} \mathrm{O}_{8} \mathrm{H} \cdot 4 \mathrm{H}_{2} \mathrm{O}\right)$, lepidocrocite $(\gamma-\mathrm{FeOOH})$, and goethite $\left.(\alpha-\mathrm{FeOOH})\right)$ as $\mathrm{Np}(\mathrm{V}) \mathrm{O}_{2}{ }^{+}$, forming inner-sphere adsorption complexes or ternary carbonate surface species; however, there is uncertainty surrounding the detailed speciation of $\mathrm{Np}$ during these interactions [12,14-16]. Furthermore, it has been suggested that $\mathrm{Np}(\mathrm{V})$ may also be incorporated into the structure of crystalline $\mathrm{Fe}(\mathrm{III})$-(oxyhydr)oxides, for example hematite $\left(\mathrm{Fe}_{2} \mathrm{O}_{3}\right)$, in a neptunate-like coordination environment [12]. Upon interaction with $\mathrm{Fe}(\mathrm{II})$-containing mineral phases, such as magnetite $\left(\mathrm{Fe}_{3} \mathrm{O}_{4}\right)$ and mackinawite $(\mathrm{FeS}), \mathrm{Np}(\mathrm{V})$ is reduced to $\mathrm{Np}(\mathrm{IV}) \mathrm{O}_{2}(\mathrm{~s})[13,21,23]$. Both sorption and co-precipitation interactions of $\mathrm{Np}(\mathrm{V})$ with magnetite result in the precipitation of $\mathrm{Np}(\mathrm{IV}) \mathrm{O}_{2}$ phases. However, when $\mathrm{Np}(\mathrm{V})$ interacts with $\mathrm{FeS}$, there is evidence for the formation of a reduced $\mathrm{Np}(\mathrm{IV})$-sulphur coordinated surface complex [18]. Unexpected actinide-sulphur environmental chemistry has recently been observed for uranium, whereby sulfidic systems have been shown to transiently increase uranium mobility [24-27], with $\mathrm{U}(\mathrm{VI})$-persulphide species implicated in this enhanced solubility [26]. There is also uncertainty surrounding the exact interaction mechanisms and products of $\mathrm{U}(\mathrm{VI})$ with mackinawite, with some studies claiming the near complete reduction of U(VI) to U(IV) [28-31], whilst others suggest partial reduction to mixed U(IV/VI) phases [17,32-34]. Given this, there is a need to further investigate and better understand both $\mathrm{Np}$ and $\mathrm{U}$ interactions with Fe(II)-containing mineral phases.

In addition to environmental interactions with iron minerals, effluent treatment facilities also utilise the sorption capacity of iron (oxyhydr)oxides to partition contaminants to the solid phase. One key example is the use of ferrihydrite to remove actinides from effluents at EARP $[8,10]$. Here, the $\mathrm{pH}$ of an acidic effluent is increased through addition of $\mathrm{NaOH}$, resulting in the formation of ferrihydrite via Keggin clusters $\left(\mathrm{Fe}_{13}\right)$ [35]. As the $\mathrm{pH}$ increases, ferrihydrite forms from the clusters and precipitates out of the solution, with the associated radionuclides, including uranium and plutonium, partitioned to the solid phase $[9,10]$. Studies have explored the speciation of $\mathrm{U}$ and $\mathrm{Pu}$ associated with the ferrihydrite end-product of precipitation in model systems, with $\mathrm{U}(\mathrm{VI})$ forming a bidentate, edge-sharing surface adsorption complex [10] in line with previous work [36], and $\mathrm{Pu}(\mathrm{IV})$ forming an inner-sphere, tetradentate complex [9]. To date, $\mathrm{Np}$ has not been investigated in this industrially relevant scenario, and so understanding the mechanism by which $\mathrm{Np}$ interacts with ferrihydrite in a co-precipitation experiment, such as a simulated EARP process, would provide new information on its behaviour, and the behaviour of $\mathrm{AnO}_{2}{ }^{+}$ ions more generally, during effluent treatment. 
In this study, the interaction of relatively low levels of $\mathrm{Np}(\mathrm{V})$ and $\mathrm{U}(\mathrm{VI})$ with various iron-bearing mineral phases has been explored using $X$-ray Absorption Spectroscopy (XAS) to better understand the speciation of actinides in environmentally and industrially relevant scenarios. $\mathrm{Np}(\mathrm{V})$ was added to systems containing ferrihydrite, goethite, and $\mathrm{FeS}$ to investigate environmental interactions with mineral phases. Additionally, U(VI) was added to a system containing FeS as a parallel experiment to the corresponding $\mathrm{Np}(\mathrm{V})$ system. Finally, in order to investigate the fate of $\mathrm{Np}(\mathrm{V})$ during ferrihydrite coprecipitation, i.e., to mimic effluent treatment, $\mathrm{Np}(\mathrm{V})$ was added to an acidic $\mathrm{Fe}(\mathrm{III})$ solution and the $\mathrm{pH}$ raised to co-precipitate $\mathrm{Np}(\mathrm{V})$ with ferrihydrite. EXAFS analysis of all systems containing $\mathrm{Fe}(\mathrm{III})$ minerals (ferrihydrite adsorption, ferrihydrite co-precipitation, and goethite) showed $\mathrm{Np}(\mathrm{V})$ adsorbing to the surface of the mineral as the neptunyl moiety. Interestingly, EXAFS analysis highlighted that only the first two shells $\left(\mathrm{O}_{\mathrm{ax}}\right.$ and $\left.\mathrm{O}_{\mathrm{eq}}\right)$ could be fitted with confidence, with no strong evidence for the Fe and/or $C$ backscatterers that would be expected for inner-sphere actinyl complexes $[12,15,16,19]$. These findings suggest that there are limitations associated with the use of EXAFS analysis for speciation determination of $\mathrm{Np}(\mathrm{V})$ in $\mathrm{Fe}(\mathrm{III})$ mineral-containing systems, particularly in establishing the presence/absence of certain shells around the central atom. Upon spiking an anaerobic slurry of $\mathrm{FeS}, \mathrm{Np}(\mathrm{V})$ was reduced to $\mathrm{Np}(\mathrm{IV})$ and precipitated as nanocrystalline $\mathrm{Np}(\mathrm{IV}) \mathrm{O}_{2}$. A similar result was seen in the analogous $\mathrm{U}(\mathrm{VI})$ system, with nanocrystalline $\mathrm{U}(\mathrm{IV}) \mathrm{O}_{2}$ present as the reaction product. These results provide significant insight into how $\mathrm{Np}$ interacts with various iron minerals present in radioactively contaminated land, geological disposal facilities, and industrial effluent treatment scenarios.

\section{Materials and Methods}

All reagents used in this study were AnalaR grade.

\subsection{Mineral Synthesis}

Synthesis of ferrihydrite (2-line) was performed using the method of Cornell Schwertmann [37]. In brief, $\mathrm{Fe}$ (III) nitrate nonahydrate was dissolved in deionised water (DIW) and the $\mathrm{pH}$ adjusted to $\mathrm{pH} 7$ with $\mathrm{NaOH}$. The resulting precipitate was washed five times with DIW and dried in a desiccator, and the structure was confirmed with powder X-ray diffraction (XRD) using an anaerobic dome on a Bruker D8 Advance Diffractometer (Karlsruhe, Germany). After determination of the slurry concentration $\left(\left[\mathrm{Fe}_{\text {total }}\right]=\sim 400 \mathrm{mmol} / \mathrm{L}\right.$ slurry) by ferrozine assay $[38,39]$, the product was stored at $4{ }^{\circ} \mathrm{C}$, and experiments were performed within one week of synthesis.

Mackinawite was synthesised by following the method of Ohfuji and Rickard to produce synthetic nanocrystalline mackinawite [40]. All work was performed in an $\mathrm{O}_{2}$-free anaerobic chamber $\left(5 \% \mathrm{H}_{2}: 95 \% \mathrm{~N}_{2} \mathrm{mix}\right)$, and all DIW used was thoroughly degassed with $\mathrm{N}_{2}$ prior to use. Briefly, $\left(\mathrm{NH}_{4}\right)_{2} \mathrm{Fe}(\mathrm{II})\left(\mathrm{SO}_{4}\right)_{2} \cdot 6 \mathrm{H}_{2} \mathrm{O}$ and $\mathrm{Na}_{2} \mathrm{~S} \cdot 9 \mathrm{H}_{2} \mathrm{O}$ were dissolved in deoxygenated DIW to produce two equimolar solutions. The two solutions were reacted together to produce a black precipitate that was washed three times with deoxygenated DIW. The resulting slurry concentration $\left(\left[\mathrm{Fe}_{\text {total }}\right)=\left[\mathrm{S}(-\mathrm{II})_{\text {total }}\right)=\sim 500 \mathrm{mmol} / \mathrm{L}\right.$ slurry $)$ was determined by ferrozine [38,39] and methylene blue [41] assays, and the product was used within $24 \mathrm{~h}$ of synthesis.

Synthesis of goethite was performed using the method of Cornell and Schwertmann [37]. After producing ferrihydrite by the method above, the slurry was heated to $70{ }^{\circ} \mathrm{C}$ for $60 \mathrm{~h}$. The resulting yellow precipitate was washed and dried at $50{ }^{\circ} \mathrm{C}$ before characterisation with XRD.

\subsection{Adsorption Experiments}

Experiments exploring the interaction of $\mathrm{Np}(\mathrm{V})$ with ferrihydrite and mackinawite used broadly the same methodology with the ferrihydrite reaction performed under oxic conditions and the mackinawite under anoxic conditions $\left(\mathrm{N}_{2}: \mathrm{H}_{2}\right.$ atmosphere, Coy Cabinet) and with anoxic reagents (purged with $\mathrm{N}_{2}$ ). $\mathrm{A}^{237} \mathrm{~Np}(\mathrm{~V})$ spike was diluted from a chemically 
prepared $\mathrm{Np}(\mathrm{V})$ top stock $(\mathrm{Np}(\mathrm{V})$ confirmed by UV-Vis spectrometry (UV-1800, Shimadzu Corportation (Kyoto, Japan))) into a $0.01 \mathrm{M} \mathrm{HCl}$ substock [3]. Following this, $\mathrm{NaCl}(10 \mathrm{mM})$ and $\mathrm{Np}(\mathrm{V})(830 \mathrm{~Bq})$ was added to a slurry (approximately $1 \mathrm{~g} / \mathrm{L}$ mineral) of ferrihydritemackinawite to produce a resulting Np concentration of $13 \mu \mathrm{M}$. The resulting slurry was gently stirred for $10 \mathrm{~min}$ then allowed to equilibrate for $24 \mathrm{~h}$. For the ferrihydrite system, adsorption experiments were performed on the benchtop with all work performed open to the atmosphere ( $\mathrm{pCO}_{2}=40 \mathrm{~Pa}$ ), with the $\mathrm{pH}$ adjusted to $\mathrm{pH} 6$ prior to equilibration. For the mackinawite system, adsorption experiments were performed in an anaerobic chamber $\left(5 \% \mathrm{H}_{2}: 95 \% \mathrm{~N}_{2}\right.$ mix; expected Eh values of approximately $-200 \mathrm{mV}$ based upon previous work performed on similar systems [26,42]), with no $\mathrm{pH}$ adjustment carried out prior to equilibration and with a measured $\mathrm{pH}$ of 9.3. The slurry was mounted on a $0.22 \mu \mathrm{m}$ filter disk by filtration before being frozen in a cryovial at $-80{ }^{\circ} \mathrm{C}$ for XAS analysis. For the mackinawite system, a parallel uranium experiment was performed using a depleted uranium spike that resulted in a solution with a $\mathrm{pH} \sim 9.3$ and $\mathrm{U}$ concentration of $13 \mu \mathrm{M}$.

For the goethite system, $\mathrm{NaCl}(10 \mathrm{mM}), \mathrm{NaHCO}_{3}(10 \mathrm{mM})$, and $\mathrm{Np}(\mathrm{V})$ (approximately $1700 \mathrm{~Bq})$ were added to a slurry $(0.1 \mathrm{~g} / \mathrm{L}$ mineral) to produce a solution with a Np concentration of $2.5 \mu \mathrm{M}$. The slurry was adjusted to $\mathrm{pH} 7$ and equilibrated for $24 \mathrm{~h}$ before centrifugation at 14,800 rpm to separate the wet goethite paste, which was then frozen in a cryovial at $-80^{\circ} \mathrm{C}$ for XAS analysis. The supernatant from the centrifuged sample was acidified into $2 \% \mathrm{HNO}_{3}$ and analysed using inductively coupled plasma mass spectrometry (ICP-MS; Agilent 7500cx (Santa Clara, CA, USA) with results showing $91 \pm 6.5 \%$ removal of $\mathrm{Np}$ from the solution.

\section{3. $N p(V)$ and $\mathrm{Fe}(\mathrm{III})$ Co-Precipitation Experiment}

The method used in this study has been previously published and used a Chemostat system (modified Applikon MiniBio) for the controlled base addition of $\mathrm{NaOH}$ to an acidic solution of $\mathrm{HNO}_{3}$ spiked with the $\mathrm{Np}(\mathrm{V})$ top stock to a starting concentration of $4.2 \mu \mathrm{M}[9,10,26,35]$. A simulated EARP effluent of $\mathrm{HNO}_{3}(1 \mathrm{M})$ and $\mathrm{Fe}(\mathrm{III})(7.16 \mathrm{mM})$ was placed into the Chemostat reaction vessel and reacted under controlled conditions with concentrated $(7 \mathrm{M})$ and then diluted $(0.2 \mathrm{M}) \mathrm{NaOH}$ to neutralise the effluent to form a ferrihydrite floc $[9,10,35]$. After initiating the experiment, $7 \mathrm{M} \mathrm{NaOH}$ was added at a rate of $1.5 \mathrm{~mL} / \mathrm{min}$ until the $\mathrm{pH}$ reached 2.3. The rate of $7 \mathrm{M} \mathrm{NaOH}$ addition was then slowed to $0.3 \mathrm{~mL} / \mathrm{min}$ until the system reached $\mathrm{pH}$ 3. Finally, $0.2 \mathrm{M} \mathrm{NaOH}$ was added at a rate of $1.5 \mathrm{~mL} / \mathrm{min}$ until the $\mathrm{pH}$ reached the end point of $\mathrm{pH} 9$. Selected samples were taken for aqueous analysis throughout the experiment by filtration to $<0.22 \mu \mathrm{m}$ using polyethersulphone filters. The filtered solution was acidified where appropriate to $2 \% \mathrm{HNO}_{3}$ and analysed using ICP-MS to obtain aqueous concentrations for $\mathrm{Np}$ and Fe. After the termination of the experiment, the resulting $\mathrm{Np}$-ferrihydrite slurry was centrifuged at 14,800 rpm for $5 \mathrm{~min}$, and the resultant paste frozen in a cryovial at $-80{ }^{\circ} \mathrm{C}$ for XAS analysis. The slurry was estimated to contain approximately $0.1 \mathrm{wt} \% \mathrm{~Np}$.

\subsection{X-ray Absorption Spectroscopy}

All samples were transported as frozen pellets in approved sample holders to Diamond Light Source (DLS) (United Kingdom) at $-80{ }^{\circ} \mathrm{C}$ in an anaerobic dry shipper. XAS was performed on the Np and $\mathrm{U} \mathrm{L}_{\mathrm{III}}$-edges $\left(\mathrm{Np} \mathrm{E}_{0}=17,610 \mathrm{eV} ; \mathrm{U} \mathrm{E}_{0}=17166 \mathrm{eV}\right)$ at DLS on either the I20 (goethite and ferrihydrite co-precipitation systems) or B18 (ferrihydrite and mackinawite ( $\mathrm{Np}$ and $\mathrm{U}$ ) systems) beamlines. Analyses were performed at $80 \mathrm{~K}$ using either a 64-element or 36-element Ge detector on I20 [43] and B18 [44], respectively. Beam damage was tested by checking the intensity of the XANES white line over multiple short scans. The shape of the XANES was also monitored, and no beam damage was observed in the samples. The Demeter software package (version 0.9.18.2) was used for data processing (Athena) and fitting (Artemis) [45]. Energy calibration for the B18 samples was performed using an yttrium foil standard run before and after the samples (K-edge $\mathrm{E}_{0}=17,038 \mathrm{eV}$ ). At the point of data collection, calibration was not possible for the I20 samples and therefore 
analysis of the XANES was not performed. For EXAFS analysis, FEFF8.5L [46] was used with a manual shift of $+20 \mathrm{eV}$ applied to the EXCHANGE card within the $\mathrm{Np}(\mathrm{V})$ standard FEFF input file (produced by substituting the $\mathrm{U}$ in a liebigite $\left(\mathrm{Ca}_{2} \mathrm{UO}_{2}\left(\mathrm{CO}_{3}\right)_{3}\right)$ structure [47] for $\mathrm{Np}$ ). Large $\mathrm{E}_{0}$ values have been previously observed within multiple $\mathrm{Np}$ EXAFS studies [12,48-54] and are likely a result of FEFF not accurately calculating potentials for transuranic elements, particularly in systems containing actinyl moieties.

\section{Results and Discussion}

\section{1. $\mathrm{Np}(\mathrm{V})$ and $\mathrm{Fe}(\mathrm{III}) \mathrm{Co}$-Precipitation Experiment Geochemical Data}

During the $\mathrm{Np}(\mathrm{V})$ and $\mathrm{Fe}(\mathrm{III})$ co-precipitation experiment, the majority of $\mathrm{Np}(\mathrm{V})$ $(86 \%$ total $\mathrm{Np}$ ) was partitioned to the solid phase by $\mathrm{pH} 8.5$ (Figure 1). Between $\mathrm{pH} 0.8$ and $\mathrm{pH} 3.9, \mathrm{Fe}_{\text {total }}(96 \%)$ was removed from the solution, which is consistent with ferrihydrite formation observed in past work [9,10]. The removal of 19\% (88 to 69\%) of the total Fe from solution between $\mathrm{pH} 0.8$ and $\mathrm{pH} 2.5$ was accompanied by removal of $16 \%$ (85 to $70 \%$ ) of the total $\mathrm{Np}(\mathrm{V})$ from solution. A similar observation was seen in a $\mathrm{Pu}(\mathrm{IV})$ and $\mathrm{Fe}(\mathrm{III})$ co-precipitation experiment performed using the same methodology, and it was suggested that $\mathrm{Pu}(\mathrm{IV})$ may be associating with the $\mathrm{Fe}_{13}$ clusters below $\mathrm{pH} 1$ and with newly formed ferrihydrite nanoparticles above $\mathrm{pH} 2$ [9]. It is possible that at low $\mathrm{pH}$ values, a fraction of the $\mathrm{Np}(\mathrm{V})$ was associated with nanoparticulate Fe(III) species, similar to Pu(IV). Whilst Fe continued to be removed from solution between $\mathrm{pH} 2.5$ and $\mathrm{pH} 3.9$, the remaining $\mathrm{Np}(\mathrm{V})$ solution concentrations remained constant $(72 \pm 2 \%)$ until $\mathrm{pH} 4.8$, with the majority of absorption taking place between $\mathrm{pH} 5.4$ and 8.5. This observation is in line with a previous study investigating $\mathrm{U}(\mathrm{VI})$ in the same EARP-based system, where $\mathrm{U}(\mathrm{VI})$ was predominantly removed between $\mathrm{pH} 4.5$ and $\mathrm{pH} 7$ through absorption to the surface of the newly formed two-line ferrihydrite [10]. At $\mathrm{pH}$ values $>2.5$, it is likely $\mathrm{Np}(\mathrm{V})$ follows a similar absorption mechanism to that of $\mathrm{U}(\mathrm{VI})$, associating with newly formed two-line ferrihydrite. Given the majority of $\mathrm{Np}(\mathrm{V})(57 \%)$ was removed at $\mathrm{pH}>2.5, \mathrm{~Np}(\mathrm{~V})$ removal from the solution was predominantly controlled by adsorption to newly formed two-line ferrihydrite.

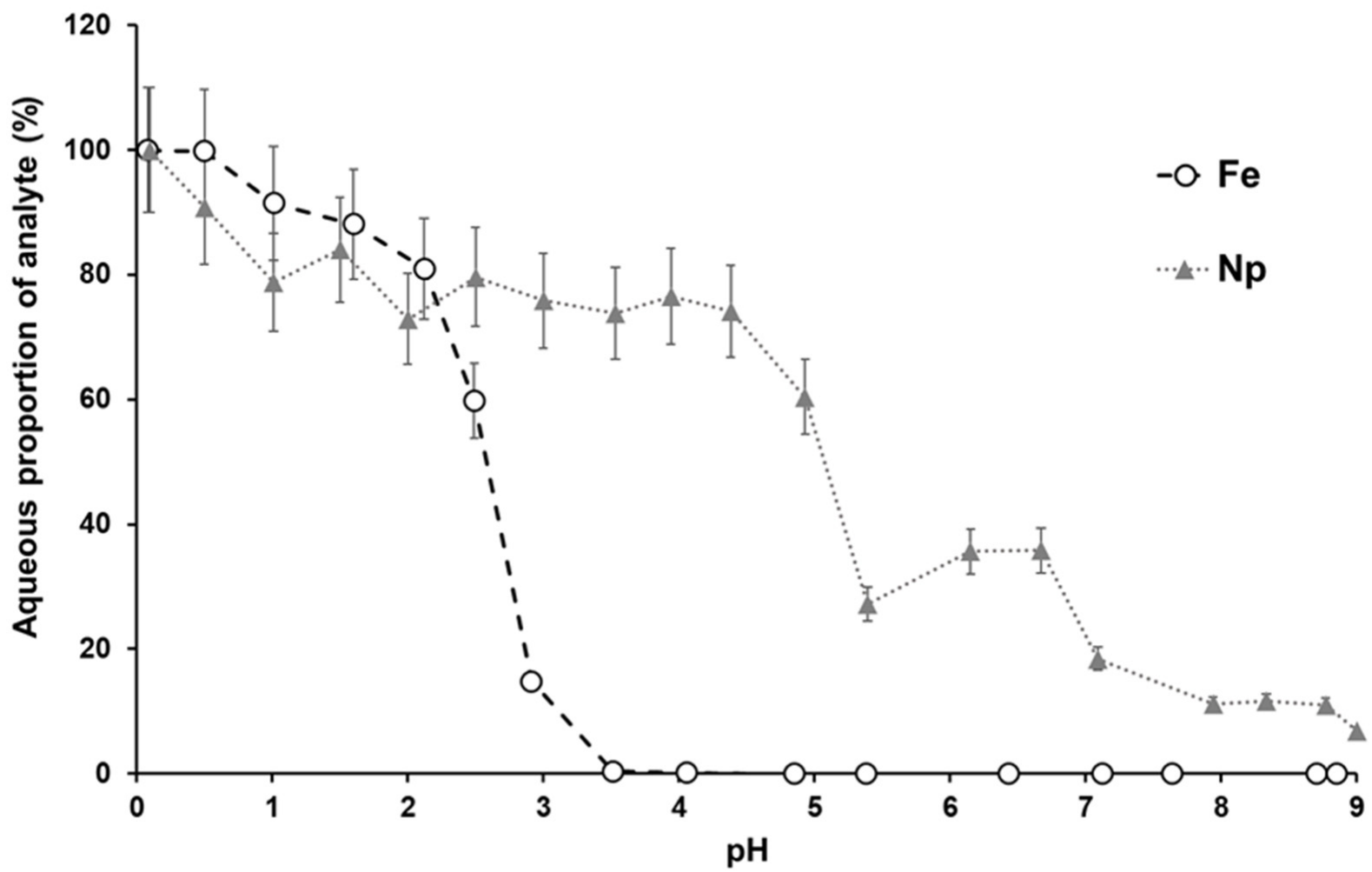

Figure 1. Np (grey triangles) and Fe (black circles) concentrations in the filtered $(<0.22 \mu \mathrm{m})$ solution from the co-precipitation experiment. Error bars are estimated at approximately $\pm 10 \%$. 


\section{2. $L_{I I I}$-Edge XAS Data}

XAS was performed on all $\mathrm{Np}(\mathrm{V})$ - and $\mathrm{U}(\mathrm{VI})$-containing samples, with data encompassing both XANES and EXAFS. Due to experimental limitations, not all data could be calibrated (with the exception of the samples $N p(V)$ on ferrihydrite and $N p(V)$ with $F e S$ ), and so XANES data were plotted relative to each sample's $\mathrm{E}_{0}$ position in order to provide the opportunity for qualitative analysis in the Supporting Information (Figure S1). The $\mathrm{Np}(\mathrm{V})$ on ferrihydrite and $\mathrm{Np}(\mathrm{V})$ with $\mathrm{FeS}$ samples were calibrated using yttrium foil runs before and after each sample (calibrated to $17,038 \mathrm{eV}$ ) and so have been plotted together for a comparison between edge positions of $\mathrm{Np}(\mathrm{V})$ and $\mathrm{Np}(\mathrm{IV})$. The XANES showed that all $\mathrm{Fe}(\mathrm{III})$-containing mineral systems (ferrihydrite and goethite) retained $\mathrm{Np}(\mathrm{V})$, with the characteristic shoulder peak that arises due to axial oxygen multiple scattering in actinyl species, present at $\sim 10 \mathrm{eV}$ above the peak of the white line [55-57]. In the $\mathrm{Fe}(\mathrm{II}) \mathrm{S}$-containing system, a reduction from $\mathrm{Np}(\mathrm{V})$ to $\mathrm{Np}(\mathrm{IV})$ was observed via the XANES, with a concomitant shift in edge position $(+2.1 \mathrm{eV}$ from $\mathrm{Np}(\mathrm{V})$ to $\mathrm{Np}(\mathrm{IV}))$ and a change in XANES features characterised by the loss of the neptunyl shoulder peak [55,57].

EXAFS modelling of both Np and U EXAFS data was performed in order to better understand the local coordination environment and interaction mechanisms of these actinides with the $\mathrm{Fe}(\mathrm{II})$ - and $\mathrm{Fe}(\mathrm{III})$-bearing minerals. For the purposes of analysis and discussion, the fits can be separated into $\mathrm{Np}(\mathrm{V})$-neptunyl sorbed to ferrihydrite and goethite and $\mathrm{Np}(\mathrm{V}) / \mathrm{U}(\mathrm{VI})$ with FeS.

\subsubsection{Np(V)-Neptunyl Sorbed to Ferrihydrite and Goethite}

According to the EXAFS modelling, all samples in Fe(III)-containing systems had neptunium present as a $\mathrm{Np}(\mathrm{V})$-neptunyl moiety, as indicated by the XANES. All three samples were modelled with the same fit, indicating that a similar speciation was present in systems where $\mathrm{Np}(\mathrm{V})$ interacts with the $\mathrm{Fe}(\mathrm{III})$-bearing iron (oxyhydr)oxides: ferrihydrite (pre-formed and co-precipitated) and goethite (Figure 2 and Table 1). The best fit model for all samples contained two O backscatterers at 1.85-1.86 $\AA$ assigned to the axial neptunyl oxygens and five O backscatterers at 2.46-2.48 $\AA$ corresponding to the oxygen atoms in the equatorial plane of the neptunyl moiety (Table 1). Fitting also considered more complex models informed by the literature, including the addition of multiple scattering pathways, splitting of the equatorial $\mathrm{O}$ shells, and additional $\mathrm{C} / \mathrm{Fe}$ backscatterers. However, for these EXAFS data, anything more than the simple two-shell fit presented resulted in a worsening of the fit (see Supporting Information for further details; Figures S2-S5 and Tables S1 and S2) [58,59]. Consequently, the previous fitting models from the literature could not be reproduced in the datasets despite similar data quality and the $k$-range being available (i.e., $k$-range fit to $~ 12$ ) $[12,15,19]$. Such challenges in speciation determination via EXAFS are evidenced in the relevant literature for a number of samples containing $\mathrm{U} / \mathrm{Np}$ associated with a variety of metal oxide minerals. Indeed, some studies have confidently fit neighbouring metal (Fe or Al) backscatterers [60-63], whilst others have noted the possibility that multiple scattering may be used as a replacement $[58,64]$, and others have not fitted any metal backscatterers $[12,16,62,63]$. This indicates that the level of detail related to the nature of the adsorption complex that may be determined from the EXAFS of $\mathrm{Np}(\mathrm{V})$ iron (oxyhydr)oxide systems may need to be reassessed. 

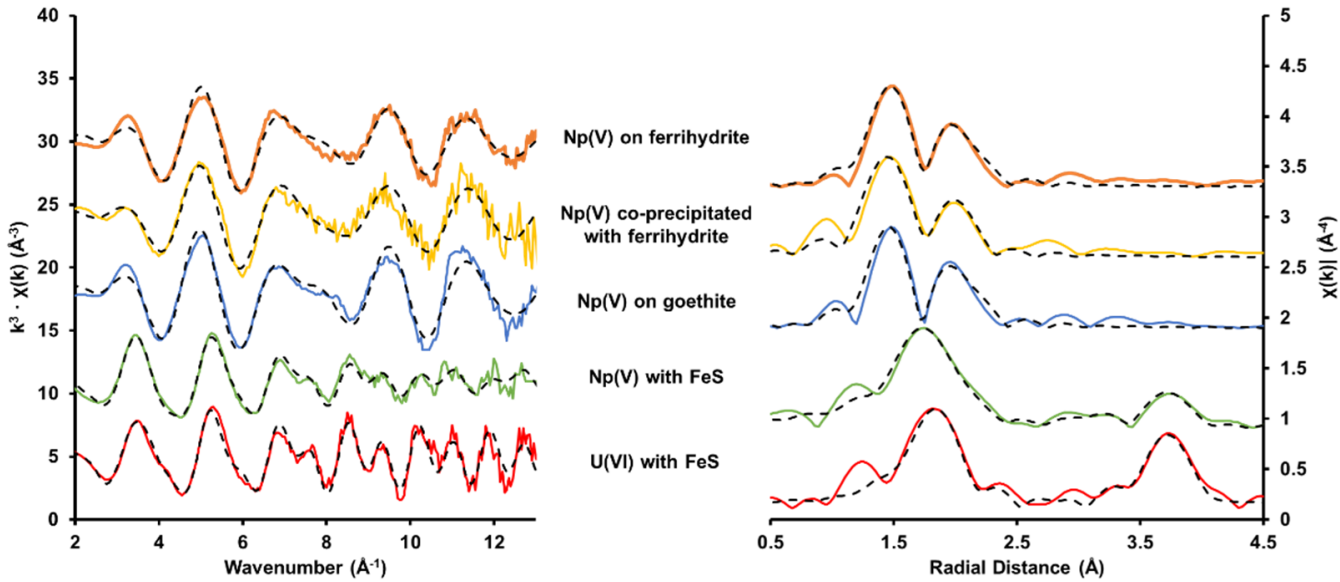

Figure 2. $\mathrm{L}_{\mathrm{III}}$-edge EXAFS spectra and simple fits for $\mathrm{Np}$ and $\mathrm{U}$ with iron mineral samples. Left: $k^{3}$-weighted EXAFS. Right: the corresponding Fourier transforms of the $k^{3}$-weighted EXAFS, using a Hanning window function. Coloured lines are the data for each given sample, and black dotted lines show the best modelled fits for the data.

Table 1. EXAFS fitting parameters for the $\mathrm{Np}$ and $\mathrm{U}$ iron mineral samples. $\mathrm{Np}(\mathrm{V})$ on ferrihydrite, $\mathrm{Np}(\mathrm{V})$ co-precipitated with ferrihydrite and $\mathrm{Np}(\mathrm{V})$ on goethite are all $\mathrm{Np}(\mathrm{V}) \mathrm{O}_{2}{ }^{+}$moieties exhibiting no reduction (for alternate fits see Supporting Information). $\mathrm{Np}(\mathrm{V})$ with $\mathrm{FeS}$ and $\mathrm{U}(\mathrm{VI})$ with FeS have both been reduced to $\mathrm{An}(\mathrm{IV}) \mathrm{O}_{2}$-like species.

\begin{tabular}{|c|c|c|c|c|c|c|c|c|c|}
\hline Experiment & Path & $\mathbf{N}$ & $\sigma^{2}\left(\AA^{2}\right)$ & $R(\AA)$ & $\mathrm{S}_{0}^{2}$ & $\Delta \mathrm{E}_{0}$ & $R$-Factor & $\begin{array}{c}k- \\
\text { Range }\end{array}$ & $\begin{array}{c}R- \\
\text { Range }\end{array}$ \\
\hline \multirow{2}{*}{$\mathrm{Np}(\mathrm{V})$ on ferrihydrite } & $\mathrm{O}_{\mathrm{ax}}$ & 2 & $0.002(1)$ & $1.86(1)$ & \multirow{2}{*}{0.9} & -2.2 & \multirow{2}{*}{0.0192} & \multirow{2}{*}{$3-13.5$} & \multirow{2}{*}{$1.25-2.7$} \\
\hline & $\mathrm{O}_{\mathrm{eq}} 1$ & 5 & $0.008(2)$ & $2.49(3)$ & & $(21)$ & & & \\
\hline \multirow{2}{*}{$\begin{array}{c}\mathrm{Np}(\mathrm{V}) \\
\text { co-precipitated with } \\
\text { ferrihydrite }\end{array}$} & $\mathrm{O}_{\mathrm{ax}}$ & 2 & $0.001(0)$ & $1.86(1)$ & \multirow[b]{2}{*}{0.9} & \multirow{2}{*}{$\begin{array}{c}-5.7 \\
(19)\end{array}$} & \multirow[b]{2}{*}{0.0168} & \multirow[b]{2}{*}{$3-12$} & \multirow[b]{2}{*}{$1.1-2.6$} \\
\hline & $\mathrm{O}_{\mathrm{eq}} 1$ & 5 & $0.009(2)$ & $2.46(2)$ & & & & & \\
\hline \multirow{2}{*}{$\mathrm{Np}(\mathrm{V})$ on goethite } & $\mathrm{O}_{\mathrm{ax}}$ & 2 & $0.001(1)$ & $1.85(1)$ & \multirow{2}{*}{1.0} & -3.5 & \multirow{2}{*}{0.0248} & \multirow{2}{*}{$3-13.5$} & \multirow{2}{*}{$1.25-2.7$} \\
\hline & $\mathrm{O}_{\mathrm{eq}} 1$ & 5 & $0.007(2)$ & $2.49(3)$ & & $(20)$ & & & \\
\hline \multirow{5}{*}{$\mathrm{Np}(\mathrm{V})$ with FeS } & O1 & 4 & $0.004(1)$ & $2.25(1)$ & \multirow{5}{*}{0.9} & \multirow{5}{*}{$5.7(1)$} & \multirow{5}{*}{0.0145} & \multirow{5}{*}{$3-11.5$} & \multirow{5}{*}{$1-4$} \\
\hline & $\mathrm{O} 2$ & 4 & $0.005(2)$ & $2.40(1)$ & & & & & \\
\hline & $\mathrm{Np} 1$ & 4 & $0.009(2)$ & $3.83(2)$ & & & & & \\
\hline & O MS1 & 24 & $0.009^{\#}$ & $3.67^{\#}$ & & & & & \\
\hline & O MS2 & 24 & $0.009^{\#}$ & $4.23^{\#}$ & & & & & \\
\hline \multirow{4}{*}{$\mathrm{U}(\mathrm{VI})$ with FeS } & O1 & 4 & $0.004(2)$ & $2.31(1)$ & \multirow{4}{*}{0.9} & \multirow{4}{*}{$6.2(10)$} & \multirow{4}{*}{0.0178} & \multirow{4}{*}{$3-12.5$} & \multirow{4}{*}{$1.4-4.6$} \\
\hline & $\mathrm{O} 2$ & 2.5 & $0.006(4)$ & $2.45(3)$ & & & & & \\
\hline & U1 & 6 & $0.006(1)$ & $3.86(1)$ & & & & & \\
\hline & $\mathrm{O}$ & 8 & $0.012(9)$ & $4.37(4)$ & & & & & \\
\hline
\end{tabular}

$\mathrm{N}$ is the degeneracy (coordination number); $\sigma^{2}$ is the Debye-Waller factor; $R$ is the interatomic distance; $\mathrm{S}_{0}^{2}$ is the amplitude reduction factor; $\Delta \mathrm{E}_{0}$ is the energy shift from the calculated Fermi level; $R$-factor is a measure of the goodness of fit; $\mathrm{O}_{\mathrm{ax}}$ is the axial oxygen scatterer of the actinyl moiety; MS represents a given multiple scattering path; " denotes that the parameters were constrained using values from both O1 and O2 paths (e.g. $\Delta R=$ delrO1 + delrO2; $\left.\sigma^{2}=\mathrm{ssO} 1+\mathrm{ssO} 2\right)$.

There was no evidence of Fe backscatterers in the simple model in contrast to some studies in similar $\mathrm{Fe}(\mathrm{III})$ (oxyhydr)oxide systems that have identified such shells between 3.40 and $3.75 \AA$ for $\mathrm{Np}(\mathrm{V})$ adsorbed to ferrihydrite and hematite $[12,15,19]$. However, the presence or absence of an iron shell in the fitting model is not inherently diagnostic of the exact neptunium surface speciation as some studies, including this work, have shown samples can only sensibly be fitted without the presence of an Fe backscatterer $[12,16]$. Additionally, previous work on $\mathrm{U}(\mathrm{VI})$-uranyl/iron (oxyhydr)oxide systems has shown that the feature within the EXAFS spectrum that is usually associated with Fe shells may 
be fitted through the addition of oxygen and carbon multiple scattering pathways [64]. This highlights the challenges in fitting a valid Fe shell to fits even for relatively simple $\mathrm{Np}(\mathrm{V}) / \mathrm{Fe}(\mathrm{III})$ (oxyhydr)oxide systems [15]. Regardless of the presence or absence of an Fe shell, previous work on neptunyl speciation generally suggest that the $\mathrm{Np}(\mathrm{V}) \mathrm{O}_{2}{ }^{+}$ moiety forms an inner-sphere bidentate complex with an iron oxide octahedron on the surface of the iron (oxyhydr)oxide mineral phase [12,15,19], some EXAFS fits also include $\mathrm{C}$ shells associated with carbonate complexation [15]. Whilst aqueous $\mathrm{Np}(\mathrm{V})$ carbonato complexes have been observed in solution [65], $\mathrm{Np}(\mathrm{V})$ carbonato complexes sorbed to iron (oxyhydr)oxides are less well constrained. Although fitting of $C$ shells was attempted in all $\mathrm{Np}(\mathrm{V})$-containing systems presented here, the fit including $\mathrm{C}$ was unsatisfactory (see Supporting Information for further details). This agrees with previous findings which suggest that $\mathrm{Np}(\mathrm{V}) \mathrm{O}_{2}{ }^{+}$complexation with carbonate is much weaker than the analogous $\mathrm{U}(\mathrm{VI}) \mathrm{O}_{2}{ }^{2+}$ system [66]. However, it should be noted that previous work has suggested that crystalline iron oxide phases (such as hematite) may encourage the formation of carbonate complexes upon sorption to the mineral surface [66]. The lack of $\mathrm{C} / \mathrm{Fe}$ shells in the fit may also be attributed to multiple $\mathrm{Np}$ species being present in the system making the detection of these more distal shells even more challenging.

Given the limitations in the EXAFS fits in this study, it was not possible to define an exact binding mechanism for $\mathrm{Np}(\mathrm{V})$ sorption to ferrihydrite and goethite, despite the fact that surface complexation models suggest that $N p(V)$ is likely to exhibit only one surface binding site with the $\mathrm{Fe}(\mathrm{III})$ (oxyhydr)oxides ferrihydrite and lepidocrocite [14,67]. Interestingly, in the systems presented in this study, EXAFS analysis alone could not determine the exact speciation of $\mathrm{Np}(\mathrm{V})$-neptunyl sorption in iron (oxyhydr)oxide containing systems. Indeed, fitting challenges have previously been discussed in other actinide/Fe-based systems, particularly in work by McBriarty et al., who recently identified the need for computationally simulated EXAFS in order to fully deconvolute the speciation of $U$ incorporated into hematite [68]. In their study, McBriarty et al. generated theoretical EXAFS spectra using hybrid functional ab initio molecular dynamics (AIMD), and combinations of these generated EXAFS spectra were compared with real EXAFS data to better understand the speciation of $U$ within hematite [68]. Indeed, this combined experimental (with greater data quality and scope, i.e., a wider $k$-range) and modelling approach may be the best toolkit in determining the exact binding mechanism $(\mathrm{s})$ of $\mathrm{Np}(\mathrm{V})$ (and actinides more generally) on Fe(III) (oxyhydr)oxides.

\subsection{2. $\mathrm{Np}(\mathrm{V})$ and $\mathrm{U}(\mathrm{VI})$ with $\mathrm{FeS}$}

On exposure to FeS, the XANES indicate that $N p(V)$ undergoes a reduction to $N p(I V)$, and this is consistent with the EXAFS fit for this sample (Figure S1). The best fit EXAFS model includes a split first $\mathrm{O}$ shell containing four $\mathrm{O}$ backscatterers at $2.25 \AA$ and four $\mathrm{O}$ backscatterers at $2.40 \AA$, and four Np backscatterers at $3.83 \AA$ (Figure 2 and Table 1). This model is consistent with an $\mathrm{Np}(\mathrm{IV}) \mathrm{O}_{2}$-like structure, and the split $\mathrm{O}$ shell and reduced $\mathrm{Np}$ coordination (from the expected 12 to 4 ) are indicative of the product being nanocrystalline, as seen with $\mathrm{U}(\mathrm{IV}) \mathrm{O}_{2}$ precipitates (including this study) $[26,69]$. Similar reaction products and resulting EXAFS models have been observed for the reduction of $\mathrm{Np}(\mathrm{V})$ in previous studies [23,70]. Interestingly, the precipitation of a $\mathrm{Np}(\mathrm{IV}) \mathrm{O}_{2}$-like phase upon reaction of $\mathrm{Np}(\mathrm{V})$ with FeS is in contrast to previous work by Moyes et al., which reported that $N p(\mathrm{~V})$ undergoes reduction at the surface of FeS to form a sulphur-coordinated inner-sphere Np(IV) complex [18]. The study by Moyes et al. utilised EXAFS to determine the local coordination environment of $\mathrm{Np}$ in this system, and the best fit model suggested that $\mathrm{Np}(\mathrm{IV})$ was coordinated by both $\mathrm{O}$ and $\mathrm{S}$ ligands, with $\mathrm{O}$ ligands originating from water molecules and S ligands from the surface of the FeS [18]. Interestingly, the Np concentration and experimental method for the $\mathrm{Np}(\mathrm{V}) / \mathrm{FeS}$ reaction were different in the Moyes et al. work compared to this study, which suggests there are complex pathways to reduction to $\mathrm{Np}(\mathrm{IV})$ in the presence of FeS. For the current work, which exposed $\mathrm{Np}(\mathrm{V})(13 \mu \mathrm{M})$ to pre-formed $\mathrm{FeS}$, the end product was nanoparticulate $\mathrm{Np}(\mathrm{IV}) \mathrm{O}_{2}$ as seen in past work under 
environmentally relevant conditions [23,70]. Alternative fitting models were trialled to test whether $\mathrm{S}$ backscatterers were present [18]; however, for the current work, no valid fit could be obtained.

As a comparison, EXAFS analysis was performed on a parallel U(VI) $(13 \mu \mathrm{M})$ reacted with an FeS sample (Figure 2 and Table 1). As with the Np/FeS system, the XANES of U in the FeS system matched well with nanocrystalline uraninite $\left(\mathrm{U}(\mathrm{IV}) \mathrm{O}_{2}\right)$, indicating reduction of U(VI) to U(IV) had taken place (Figure S5). Here, the best fitting model included a split first $\mathrm{O}$ shell containing four O backscatterers at $2.31 \AA$ and two and half $\mathrm{O}$ backscatterers at $2.45 \AA$, six U backscatterers at $3.86 \AA$, and eight distal O backscatterers at $4.37 \AA$. This is consistent with a nanoparticulate $\mathrm{U}(\mathrm{IV}) \mathrm{O}_{2}$-like structure $[26,69]$ and highlights the similarities between the $\mathrm{Np}(\mathrm{V})$ and $\mathrm{U}(\mathrm{VI})$ behaviour in these systems. There are conflicting results within the literature surrounding the extent of reduction that takes place in a $\mathrm{U}(\mathrm{VI}) / \mathrm{FeS}$ system, with some studies suggesting complete reduction to U(IV) [28-31] and others suggesting partial reduction resulting in mixed $\mathrm{U}(\mathrm{IV}) / \mathrm{U}(\mathrm{VI})$-containing systems $[17,32,33]$. The results from the current work suggest that upon interaction with FeS, $\mathrm{U}(\mathrm{VI})$ is reduced completely to nanoparticulate $\mathrm{U}(\mathrm{IV}) \mathrm{O}_{2}$ over a $24 \mathrm{~h}$ equilibration period. Explanations for the discrepancies in reactivity in comparison to previous studies may be due to the different $\mathrm{FeS}$ synthesis methods employed and/or $\mathrm{pH}$ and concentration effects. As with the $\mathrm{Np} / \mathrm{FeS}$ system, regardless of the exact speciation of $U$ in these systems, the interaction between $\mathrm{U}(\mathrm{VI})$ and $\mathrm{FeS}$ results in a strong partitioning to the solid phase, with this study suggesting the formation of nanoparticulate $\mathrm{U}(\mathrm{IV}) \mathrm{O}_{2}$.

\section{Conclusions}

When employing effective environmental and industrial technologies, such as those at the EARP facilities or when considering radioactive waste disposal and contaminated land scenarios, it is important to fully understand the molecular scale speciation and fate of actinides. This study has highlighted the challenges associated with defining the exact speciation of $\mathrm{Np}$ interactions with iron (oxyhydr)oxide and sulfide minerals in experiments at relatively low levels of $\mathrm{Np}$ whilst also showing the tendency of $\mathrm{Np}$ to strongly partition to these solids. Through a combination of geochemical and EXAFS solid phase analysis, on interaction with $\mathrm{Fe}(\mathrm{III})$ (oxhydr)oxides (goethite and ferrihydrite (both preformed and coprecipitated)), $\mathrm{Np}(\mathrm{V})$ adsorbs to the surface of the mineral phase as a $\mathrm{Np}(\mathrm{V}) \mathrm{O}_{2}{ }^{+}$neptunyl moiety. Developing further insight into the exact $\mathrm{Np}(\mathrm{V})$ speciation, including the presence of absence of Fe and $C$ shells in the fitting models, was challenging. This suggests that there are limitations in using EXAFS alone to understand the details surrounding transuranic actinyl speciation when interacting with iron (oxyhydr)oxides/sulfides, and the move towards multi-technique approaches to speciation determination is important. When $\mathrm{Np}(\mathrm{V})$ interacts with the Fe(II)-containing mineral FeS, reduction to $\mathrm{Np}$ (IV) was observed, with the product being nanoparticulate $\mathrm{Np}(\mathrm{IV}) \mathrm{O}_{2}$. This result was mirrored in the analogous $\mathrm{U}(\mathrm{VI}) / \mathrm{FeS}$ system, which again displayed complete reduction to nanoparticulate $\mathrm{U}(\mathrm{IV}) \mathrm{O}_{2}$. These results provide insight into how both $\mathrm{Np}$ and $\mathrm{U}$ may behave in systems, industrial or environmental, that alter actinide environmental mobility.

Supplementary Materials: The following are available online at https://www.mdpi.com/article/10 .3390/min12020165/s1, Figure S1: Np L III-edge XANES spectra of the Np with iron mineral samples, Figure S2: Alternate fit options for the $\mathrm{Np} \mathrm{L}$ III-edge EXAFS data from the $\mathrm{Np}(\mathrm{V})$ on ferrihydrite, $\mathrm{Np}(\mathrm{V})$ co-precipitated with ferrihydrite, and $\mathrm{Np}(\mathrm{V})$ on goethite systems, Table S1: EXAFS fitting parameters for the different models (1-4) shown in Figure S2, Figure S3: Np L III-edge EXAFS spectra from the $\mathrm{Np}(\mathrm{V})$ in goethite system with different fitting models to accommodate multiple scattering pathways, Table S2: EXAFS fitting parameters for the $\mathrm{Np}(\mathrm{V})$ on goethite models shown in Figure S3, demonstrating the effect of adding multiple scattering pathways to the fit, Figure S4: EXAFS $k$-space plot of the $\mathrm{Np}(\mathrm{V})$ on goethite sample showing the data, the Model $1 \mathrm{~A}$ fit, and the $\mathrm{O}_{\mathrm{ax}}$ multiple scattering pathways (forward through absorber, non-forward through absorber, and rattle). Figure S5: U L III-edge XANES spectra of U(VI) with FeS and two end member species (U(VI) 
adsorbed to ferrihydrite and nanocrystalline uraninite (U(IV) $\left.\mathrm{O}_{2}\right)$ ) standards taken from previous work. Reference [71] is cited in Supplementary Materials.

Author Contributions: Conceptualization, L.T.T., K.M. and S.S.; methodology, L.T.T., K.F.S., E.H.W., O.S., K.M. and S.S.; validation, K.F.S., J.F.W.M., F.R.L., K.M. and S.S.; formal analysis, L.T.T., K.F.S. and E.H.W.; investigation, L.T.T., K.F.S., E.H.W. and O.S.; data curation, L.T.T., K.F.S. and E.H.W.; writing—original draft preparation, L.T.T.; writing—review and editing, L.T.T., K.F.S., K.M., J.F.W.M., F.R.L. and S.S.; visualization, L.T.T. and K.F.S.; supervision, L.A.-M., R.B., K.M. and S.S.; project administration, L.A.-M., R.B., K.M. and S.S.; funding acquisition, L.T.T., K.M. and S.S. All authors have read and agreed to the published version of the manuscript.

Funding: This research was funded by the EPSRC through the EPSRC Doctoral Prize fund (EP/ R513131/1) in supporting L.T.T, the STFC EnvRadNet-2 proposal (ST/N002474/1) in supporting K.F.S, and Diamond Light Source beamtime awards (SP24074-2, SP21441-4, SP13559-5, SP13559-6). We also acknowledge access to the EPSRC NNUF RADER Facility (EP/T011300/1) for analyses performed in this work.

Acknowledgments: The authors would like to thank Sellafield, the University of Manchester, and NNL Effluents Centre of Expertise in supporting E.H.W. The authors thank Shu Hayama, Giannantonio Cibin, and Steve Parry for their beamline assistance. The authors also thank Paul Lythgoe for his assistance in data acquisition.

Conflicts of Interest: The authors declare no conflict of interest.

\section{References}

1. Kaszuba, J.P.; Runde, W.H. The Aqueous Geochemistry of Neptunium: Dynamic Control of Soluble Concentrations with Applications to Nuclear Waste Disposal. Environ. Sci. Technol. 1999, 33, 4427-4433. [CrossRef]

2. Thompson, R.C. Neptunium: The Neglected Actinide: A Review of the Biological and Environmental Literature. Radiat. Res. 1982, 90, 1-32. [CrossRef] [PubMed]

3. Law, G.T.W.; Geissler, A.; Lloyd, J.R.; Livens, F.R.; Boothman, C.; Begg, J.D.C.; Denecke, M.A.; Rothe, J.; Dardenne, K.; Burke, I.T.; et al. Geomicrobiological Redox Cycling of the Transuranic Element Neptunium. Environ. Sci. Technol. 2010, 44, 8924-8929. [CrossRef] [PubMed]

4. Newsome, L.; Morris, K.; Lloyd, J.R. The Biogeochemistry and Bioremediation of Uranium and Other Priority Radionuclides. Chem. Geol. 2014, 363, 164-184. [CrossRef]

5. Thorpe, C.L.; Morris, K.; Lloyd, J.R.; Denecke, M.A.; Law, K.A.; Dardenne, K.; Boothman, C.; Bots, P.; Law, G.T.W. Neptunium and Manganese Biocycling in Nuclear Legacy Sediment Systems. Appl. Geochem. 2015, 63, 303-309. [CrossRef]

6. Nenot, J.C. Metabolism and Toxicity of Neptunium; No. AAEC-LIB/TRANS-780; Australian Atomic Energy Commission Research Establishment: Lucas Heights, Australia, 1983; p. 18.

7. Lieser, K.; Mühlenweg, U. Neptunium in the Hydrosphere and in the Geosphere: I. Chemistry of Neptunium in the Hydrosphere and Sorption of Neptunium from Groundwaters on Sediments under Aerobic and Anaerobic Conditions. Radiochim. Acta 1988, 43, 27-36. [CrossRef]

8. Wilson, P.D. The Nuclear Fuel Cycle from Ore to Wastes; Oxford University Press: Oxford, UK, 1996.

9. Smith, K.F.; Morris, K.; Law, G.T.W.; Winstanley, E.H.; Livens, F.R.; Weatherill, J.S.; Abrahamsen-Mills, L.G.; Bryan, N.D.; Mosselmans, J.F.W.; Cibin, G.; et al. Plutonium(Iv) Sorption During Ferrihydrite Nanoparticle Formation. ACS Earth Space Chem. 2019, 3, 2437-2442. [CrossRef]

10. Winstanley, E.H.; Morris, K.; Abrahamsen-Mills, L.G.; Blackham, R.; Shaw, S. U(Vi) Sorption During Ferrihydrite Formation: Underpinning Radioactive Effluent Treatment. J. Hazard. Mater. 2019, 366, 98-104. [CrossRef]

11. Li, D.; Kaplan, D.I. Sorption Coefficients and Molecular Mechanisms of Pu, U, Np, Am and Tc to Fe (Hydr)Oxides: A Review. J. Hazard. Mater. 2012, 243, 1-18. [CrossRef]

12. Bots, P.; Shaw, S.; Law, G.T.W.; Marshall, T.A.; Mosselmans, J.F.W.; Morris, K. Controls on the Fate and Speciation of Np(V) During Iron (Oxyhydr)Oxide Crystallization. Environ. Sci. Technol. 2016, 50, 3382-3390. [CrossRef]

13. Bots, P.; van Veelen, A.; Mosselmans, F.W.J.; Muryn, C.; Wogelius, A.R.; Morris, K. Neptunium(V) and Uranium(Vi) Reactions at the Magnetite (111) Surface. Geosciences 2019, 9, 81. [CrossRef]

14. Yang, C.; Powell, B.A.; Zhang, S.; Rao, L. Surface Complexation Modeling of Neptunium (V) Sorption to Lepidocrocite ( $\Gamma$-Feooh). Radiochim. Acta 2015, 103, 707-717. [CrossRef]

15. Arai, Y.; Moran, P.; Honeyman, B.; Davis, J. In Situ Spectroscopic Evidence for Neptunium (V)-Carbonate Inner-Sphere and Outer-Sphere Ternary Surface Complexes on Hematite Surfaces. Environ. Sci. Technol. 2007, 41, 3940-3944. [CrossRef] [PubMed]

16. Combes, J.M.; Chisholm-Brause, C.J.; Brown, G.E.; Parks, G.A.; Conradson, S.D.; Eller, P.G.; Triay, I.R.; Hobart, D.E.; Miejer, A. Exafs Spectroscopic Study of Neptunium(V) Sorption at the A-Feooh/Water Interface. Environ. Sci. Technol. 1992, 26, 376-382. [CrossRef] 
17. Livens, F.R.; Jones, M.J.; Hynes, A.J.; Charnock, J.M.; Mosselmans, J.F.W.; Hennig, C.; Steele, H.; Collison, D.; Vaughan, D.J.; Pattrick, R.A.D.; et al. X-ray Absorption Spectroscopy Studies of Reactions of Technetium, Uranium and Neptunium with Mackinawite. J. Environ. Radioact. 2004, 74, 211-219. [CrossRef]

18. Moyes, L.N.; Jones, M.J.; Reed, W.A.; Livens, F.R.; Charnock, J.M.; Mosselmans, J.F.W.; Hennig, C.; Vaughan, D.J.; Pattrick, R.A.D. An X-ray Absorption Spectroscopy Study of Neptunium(V) Reactions with Mackinawite (Fes). Environ. Sci. Technol. 2002, 36, 179-183. [CrossRef]

19. Müller, K.; Gröschel, A.; Rossberg, A.; Bok, F.; Franzen, C.; Brendler, V.; Foerstendorf, H. In Situ Spectroscopic Identification of Neptunium (V) Inner-Sphere Complexes on the Hematite-Water Interface. Environ. Sci. Technol. 2015, 49, 2560-2567. [CrossRef]

20. Nakata, K.; Nagasaki, S.; Tanaka, S.; Sakamoto, Y.; Tanaka, T.; Ogawa, H. Reduction Rate of Neptunium (V) in Heterogeneous Solution with Magnetite. Radiochim. Acta 2004, 92, 145-150. [CrossRef]

21. Roberts, H.E.; Morris, K.; Mosselmans, J.F.W.; Law, G.T.W.; Shaw, S. Neptunium Reactivity During Co-Precipitation and Oxidation of Fe(II)/Fe(III) (Oxyhydr)Oxides. Geosciences 2019, 9, 27. [CrossRef]

22. Henderson, A.D.; Demond, A.H. Permeability of Iron Sulfide (Fes)-Based Materials for Groundwater Remediation. Water Res. 2013, 47, 1267-1276. [CrossRef]

23. Brookshaw, D.R.; Pattrick, R.A.; Bots, P.; Law, G.T.; Lloyd, J.R.; Mosselmans, J.F.W.; Vaughan, D.J.; Dardenne, K.; Morris, K. Redox Interactions of Tc (Vii), U (Vi), and Np (V) with Microbially Reduced Biotite and Chlorite. Environ. Sci. Technol. 2015, 49, 13139-13148. [CrossRef] [PubMed]

24. Alexandratos, V.G.; Behrends, T.; Van Cappellen, P. Sulfidization of Lepidocrocite and Its Effect on Uranium Phase Distribution and Reduction. Geochim. Cosmochim. Acta 2014, 142, 570-586. [CrossRef]

25. Alexandratos, V.G.; Behrends, T.; Van Cappellen, P. Fate of Adsorbed U(Vi) During Sulfidization of Lepidocrocite and Hematite. Environ. Sci. Technol. 2017, 51, 2140-2150. [CrossRef]

26. Townsend, L.T.; Shaw, S.; Ofili, N.E.R.; Kaltsoyannis, N.; Walton, A.S.; Mosselmans, J.F.W.; Neill, T.S.; Lloyd, J.R.; Heath, S.; Hibberd, R.; et al. Formation of a U(Vi)-Persulfide Complex During Environmentally Relevant Sulfidation of Iron (Oxyhydr)Oxides. Environ. Sci. Technol. 2020, 54, 129-136. [CrossRef] [PubMed]

27. Sun, Y.; Lan, J.; Li, M.; Hu, W.; Liu, H.; Song, G.; Chen, D.; Shi, W.; Wang, X. Influence of Aqueous Sulfide on Speciation of U(Vi) Adsorbed to Nanomagnetite. Environ. Sci. Nano 2018, 5, 1981-1989. [CrossRef]

28. Gallegos, T.J.; Fuller, C.C.; Webb, S.M.; Betterton, W. Uranium(Vi) Interactions with Mackinawite in the Presence and Absence of Bicarbonate and Oxygen. Environ. Sci. Technol. 2013, 47, 7357-7364. [CrossRef]

29. Lee, S.Y.; Cha, W.S.; Kim, J.-G.; Baik, M.H.; Jung, E.C.; Jeong, J.T.; Kim, K.; Chung, S.Y.; Lee, Y.J. Uranium(Iv) Remobilization under Sulfate Reducing Conditions. Chem. Geol. 2014, 370, 40-48. [CrossRef]

30. Hyun, S.P.; Davis, J.A.; Sun, K.; Hayes, K.F. Uranium(Vi) Reduction by Iron(Ii) Monosulfide Mackinawite. Environ. Sci. Technol. 2012, 46, 3369-3376. [CrossRef]

31. Veeramani, H.; Scheinost, A.C.; Monsegue, N.; Qafoku, N.P.; Kukkadapu, R.; Newville, M.; Lanzirotti, A.; Pruden, A.; Murayama, M.; Hochella, M.F. Abiotic Reductive Immobilization of U(Vi) by Biogenic Mackinawite. Environ. Sci. Technol. 2013, 47, 2361-2369. [CrossRef]

32. Hua, B.; Deng, B. Reductive Immobilization of Uranium(Vi) by Amorphous Iron Sulfide. Environ. Sci. Technol. 2008, 42, 8703-8708 [CrossRef]

33. Moyes, L.N.; Parkman, R.H.; Charnock, J.M.; Vaughan, D.J.; Livens, F.R.; Hughes, C.R.; Braithwaite, A. Uranium Uptake from Aqueous Solution by Interaction with Goethite, Lepidocrocite, Muscovite, and Mackinawite: An X-ray Absorption Spectroscopy Study. Environ. Sci. Technol. 2000, 34, 1062-1068. [CrossRef]

34. Ofili, N.E.R.; Thetford, A.; Kaltsoyannis, N. Adsorption of U(Vi) on Stoichiometric and Oxidised Mackinawite: A Dft Study. Environ. Sci. Technol. 2020, 54, 6792-6799. [CrossRef] [PubMed]

35. Weatherill, J.S.; Morris, K.; Bots, P.; Stawski, T.M.; Janssen, A.; Abrahamsen, L.; Blackham, R.; Shaw, S. Ferrihydrite Formation: The Role of $\mathrm{Fe}_{13}$ Keggin Clusters. Environ. Sci. Technol. 2016, 50, 9333-9342. [CrossRef] [PubMed]

36. Waite, T.D.; Davis, J.A.; Payne, T.E.; Waychunas, G.A.; Xu, N. Uranium(Vi) Adsorption to Ferrihydrite: Application of a Surface Complexation Model. Geochim. Cosmochim. Acta 1994, 58, 5465-5478. [CrossRef]

37. Cornell, R.M.; Schwertmann, U. Synthesis. In The Iron Oxides; Wiley-VCH Verlag GmbH \& Co. KGaA.: Weinheim, Germany, 2004; pp. 525-540.

38. Stookey, L.L. Ferrozine-A New Spectrophotometric Reagent for Iron. Anal. Chem. 1970, 42, 779-781. [CrossRef]

39. Viollier, E.; Inglett, P.W.; Hunter, K.; Roychoudhury, A.N.; Van Cappellen, P. The Ferrozine Method Revisited: Fe(Ii)/Fe(Iii) Determination in Natural Waters. Appl. Geochem. 2000, 15, 785-790. [CrossRef]

40. Ohfuji, H.; Rickard, D. High Resolution Transmission Electron Microscopic Study of Synthetic Nanocrystalline Mackinawite. Earth Planet. Sci. Lett. 2006, 241, 227-233. [CrossRef]

41. Fonselius, S.; Dyrssen, D.; Yhlen, B. Determination of Hydrogen Sulphide. In Methods of Seawater Analysis; Wiley-VCH Verlag GmbH: Weinheim, Germany, 2007; pp. 91-100.

42. Townsend, L.T.; Morris, K.; Harrison, R.; Schacherl, B.; Vitova, T.; Kovarik, L.; Pearce, C.I.; Mosselmans, J.F.W.; Shaw, S. Sulfidation of Magnetite with Incorporated Uranium. Chemosphere 2021, 276, 130117. [CrossRef]

43. Diaz-Moreno, S.; Hayama, S.; Amboage, M.; Freeman, A.; Sutter, J.; Duller, G. I20; the Versatile X-ray Absorption Spectroscopy Beamline at Diamond Light Source. J. Phys. Conf. Ser. 2009, 190, 012038. [CrossRef] 
44. Dent, A.; Cibin, G.; Ramos, S.; Smith, A.; Scott, S.; Varandas, L.; Pearson, M.; Krumpa, N.; Jones, C.; Robbins, P. B18: A Core Xas Spectroscopy Beamline for Diamond. J. Phys. Conf. Ser. 2009, 190, 012039. [CrossRef]

45. Ravel, B.; Newville, M. Athena, Artemis, Hephaestus: Data Analysis for X-ray Absorption Spectroscopy Using Ifeffit. J. Synchrotron Radiat. 2005, 12, 537-541. [CrossRef]

46. Ankudinov, A.L.; Ravel, B.; Rehr, J.J.; Conradson, S.D. Real-Space Multiple-Scattering Calculation and Interpretation of X-rayAbsorption near-Edge Structure. Phys. Rev. B 1998, 58, 7565-7576. [CrossRef]

47. Mereiter, K. The Crystal Structure of Liebigite, $\mathrm{Ca}_{2} \mathrm{uo}_{2}\left(\mathrm{Co}_{3}\right)_{3} \cdot \sim 11 \mathrm{~h}_{2} \mathrm{o}$. Tschermaks Mineral. Petrogr. Mitt. 1982, 30, $277-288$. [CrossRef]

48. Carter, K.P.; Smith, K.F.; Tratnjek, T.; Shield, K.M.; Moreau, L.M.; Rees, J.A.; Booth, C.H.; Abergel, R.J. Spontaneous ChelationDriven Reduction of the Neptunyl Cation in Aqueous Solution. Chem. Eur. J. 2020, 26, 2354-2359. [CrossRef]

49. Sachs, S.; Schmeide, K.; Reich, T.; Brendler, V.; Heise, K.H.; Bernhard, G. Exafs Study on the Neptunium(V) Complexation by Various Humic Acids under Neutral Ph Conditions. Radiochim. Acta 2005, 93, 17. [CrossRef]

50. Giandomenico, M.V.D.; Naour, C.L.; Simoni, E.; Guillaumont, D.; Moisy, P.; Hennig, C.; Conradson, S.D.; Auwer, C.D. Structure of Early Actinides(V) in Acidic Solutions. Radiochim. Acta 2009, 97, 347. [CrossRef]

51. Gaona, X.; Tits, J.; Dardenne, K.; Liu, X.; Rothe, J.; Denecke, M.A.; Wieland, E.; Altmaier, M. Spectroscopic Investigations of $\mathrm{Np}(\mathrm{V} / \mathrm{Vi})$ Redox Speciation in Hyperalkaline Tma-(Oh, Cl) Solutions. Radiochim. Acta 2012, 100, 759. [CrossRef]

52. Fröhlich, D.R.; Amayri, S.; Drebert, J.; Grolimund, D.; Huth, J.; Kaplan, U.; Krause, J.; Reich, T. Speciation of Np(V) Uptake by Opalinus Clay Using Synchrotron Microbeam Techniques. Anal. Bioanal. Chem. 2012, 404, 2151-2162. [CrossRef]

53. Gaona, X.; Wieland, E.; Tits, J.; Scheinost, A.C.; Dähn, R. Np(V/Vi) Redox Chemistry in Cementitious Systems: Xafs Investigations on the Speciation under Anoxic and Oxidizing Conditions. Appl. Geochem. 2013, 28, 109-118. [CrossRef]

54. Maiwald, M.M.; Dardenne, K.; Rothe, J.; Skerencak-Frech, A.; Panak, P.J. Thermodynamics and Structure of Neptunium(V) Complexes with Formate. Spectroscopic and Theoretical Study. Inorg. Chem. 2020, 59, 6067-6077. [CrossRef]

55. Denecke, M.A.; Dardenne, K.; Marquardt, C.M. Np(Iv)/Np(V) Valence Determinations from Np $\mathrm{L}_{3}$ Edge Xanes/Exafs. Talanta 2005, 65, 1008-1014. [CrossRef] [PubMed]

56. Hudson, E.A.; Allen, P.G.; Terminello, L.J.; Denecke, M.A.; Reich, T. Polarized X-ray-Absorption Spectroscopy of the Uranyl Ion: Comparison of Experiment and Theory. Phys. Rev. B 1996, 54, 156-165. [CrossRef] [PubMed]

57. Soderholm, L.; Antonio, M.R.; Williams, C.; Wasserman, S.R. Xanes Spectroelectrochemistry: A New Method for Determining Formal Potentials. Anal. Chem. 1999, 71, 4622-4628. [CrossRef]

58. Elo, O.; Müller, K.; Ikeda-Ohno, A.; Bok, F.; Scheinost, A.C.; Hölttä, P.; Huittinen, N. Batch Sorption and Spectroscopic Speciation Studies of Neptunium Uptake by Montmorillonite and Corundum. Geochim. Cosmochim. Acta 2017, 198, 168-181. [CrossRef]

59. Forbes, T.Z.; Burns, P.C.; Skanthakumar, S.; Soderholm, L. Synthesis, Structure, and Magnetism of Np2o5. J. Am. Chem. Soc. 2007, 129, 2760-2761. [CrossRef]

60. Krawczyk-Bärsch, E.; Scheinost, A.C.; Rossberg, A.; Müller, K.; Bok, F.; Hallbeck, L.; Lehrich, J.; Schmeide, K. Uranium and Neptunium Retention Mechanisms in Gallionella Ferruginea/Ferrihydrite Systems for Remediation Purposes. Environ. Sci. Pollut. Res. 2021, 28, 18342-18353. [CrossRef]

61. Ulrich, K.-U.; Rossberg, A.; Foerstendorf, H.; Zänker, H.; Scheinost, A.C. Molecular Characterization of Uranium(Vi) Sorption Complexes on Iron(Iii)-Rich Acid Mine Water Colloids. Geochim. Cosmochim. Acta 2006, 70, 5469-5487. [CrossRef]

62. Rossberg, A.; Ulrich, K.-U.; Weiss, S.; Tsushima, S.; Hiemstra, T.; Scheinost, A.C. Identification of Uranyl Surface Complexes on Ferrihydrite: Advanced Exafs Data Analysis and Cd-Music Modeling. Environ. Sci. Technol. 2009, 43, 1400-1406. [CrossRef]

63. Dodge, C.J.; Francis, A.J.; Gillow, J.B.; Halada, G.P.; Eng, C.; Clayton, C.R. Association of Uranium with Iron Oxides Typically Formed on Corroding Steel Surfaces. Environ. Sci. Technol. 2002, 36, 3504-3511. [CrossRef]

64. Sherman, D.M.; Peacock, C.L.; Hubbard, C.G. Surface Complexation of U(Vi) on Goethite (A-Feooh). Geochim. Cosmochim. Acta 2008, 72, 298-310. [CrossRef]

65. Clark, D.L.; Conradson, S.D.; Ekberg, S.A.; Hess, N.J.; Neu, M.P.; Palmer, P.D.; Runde, W.; Tait, C.D. Exafs Studies of Pentavalent Neptunium Carbonato Complexes. Structural Elucidation of the Principal Constituents of Neptunium in Groundwater Environments. J. Am. Chem. Soc. 1996, 118, 2089-2090. [CrossRef]

66. Gagliardi, L.; Roos, B.O. Coordination of the Neptunyl Ion with Carbonate Ions and Water: A Theoretical Study. Inorg. Chem. 2002, 41, 1315-1319. [CrossRef] [PubMed]

67. Girvin, D.C.; Ames, L.L.; Schwab, A.P.; McGarrah, J.E. Neptunium Adsorption on Synthetic Amorphous Iron Oxyhydroxide. J. Colloid Interface Sci. 1991, 141, 67-78. [CrossRef]

68. McBriarty, M.E.; Kerisit, S.; Bylaska, E.J.; Shaw, S.; Morris, K.; Ilton, E.S. Iron Vacancies Accommodate Uranyl Incorporation into Hematite. Environ. Sci. Technol. 2018, 52, 6282-6290. [CrossRef] [PubMed]

69. Burgos, W.D.; McDonough, J.T.; Senko, J.M.; Zhang, G.; Dohnalkova, A.C.; Kelly, S.D.; Gorby, Y.; Kemner, K.M. Characterization of Uraninite Nanoparticles Produced by Shewanella Oneidensis Mr-1. Geochim. Cosmochim. Acta 2008, 72, 4901-4915. [CrossRef]

70. Husar, R.; Hübner, R.; Hennig, C.; Martin, P.M.; Chollet, M.; Weiss, S.; Stumpf, T.; Zänker, H.; Ikeda-Ohno, A. Intrinsic Formation of Nanocrystalline Neptunium Dioxide under Neutral Aqueous Conditions Relevant to Deep Geological Repositories. Chem. Commun. 2015, 51, 1301-1304. [CrossRef]

71. Catalano, J.G.; Brown, G.E. Uranyl Adsorption onto Montmorillonite: Evaluation of Binding Sites and Carbonate Complexation. Geochim. Cosmochim. Acta 2005, 69, 2995-3005. [CrossRef] 